\title{
Creative Accounting or Fraud? Ethical Perceptions Among Accountants
}

\author{
TÂNIA ALVES DE JESUS \\ Lisbon Accounting and Business School \\ Email: tajesus@iscal.ipl.pt \\ Tel: +351217984500 \\ PEDRO PINHEIRO \\ Lisbon Accounting and Business School \\ Email: pmpinheiro@iscal.ipl.pt \\ Tel: +351217984500 \\ CATARINA KAIZELER \\ Lisbon Accounting and Business School \\ Email: ackaizeler@iscal.ipl.pt \\ Tel: +351217984500 \\ MANUELA SARMENTO \\ Lusíada University \\ Email: manuela.sarmento2@gmail.com \\ Tel: +351213611500
}

\begin{abstract}
In the current context of economic and financial worldwide crisis, the integration of accounting and ethics is urgent, emphasizing an ethical dimension that triggers a new perspective on financial reporting so that accounting can promote economic recovery. This research is about accounting environment and the risk of fraud, investigating the relationship between creative accounting and ethics. It presents and defines the concepts of creative accounting, accounting fraud and other associated terms. In order to analyse the level of discomfort accountants perceive towards decisions that involve creative and fraudulent accounting practices, it was constructed a survey sent to 168 accountants, from 37 companies listed on Euronext Lisbon. Based on the data obtained from the responses to the survey and the statistical analysis performed, five dimensions creative accounting were identified. Accountants identify manipulation practices that are closer to fraud and that violate accounting and financial reporting standards and identify less creative practices which include less fraud and are more ethical creative accounting practices. It is concluded that although there is no exact definition of fraud in financial reporting widely accepted in all countries, nor consensus on the distinction between fraud and creative accounting, accountants present different degrees of discomfort in ethical terms before practices of fraud and creative accounting. Therefore, it seems that creative accounting practices are not fraud.
\end{abstract}

Keywords: Financial Reporting, Earnings Management, Ethics, Fraud, Manipulation.

\section{Introduction}

There are many known accounting scandals and creative and fraudulent accounting practices, some of which, due to their size, contributed to the crisis and consequent economic recession worldwide. Examples 
in the USA are Enron, Arthur Andersen, Adelphia, Xerox and WorldCom (Stiglitz, 2003), and in Europe Ahold and Parmalat (Jones, 2011).

This research is about creative accounting environment and the risk of fraud. It exposes and analyses the association between creative accounting and decisions that address ethical accounting issues. First it is presented and defined the concepts of creative accounting and fraud in accounting and the associated terms earnings management, earnings manipulation, earnings straightening, big bath accounting, aggressive accounting, conservative accounting, and impression management. Subsequently, the economic environment of creative and fraudulent accounting is described and the motivations for creative accounting practices are explained. Finally, it is investigated the association between creative accounting and ethics, analyzing the level of discomfort accountants perceive towards decisions that involve creative and fraudulent accounting practices.

\section{Knowledge Gap}

At present, and even with the ongoing process of international accounting harmonization, there is still the existence of a certain degree of subjectivity in the application of techniques and standards that guide the accounting work, without necessarily resulting in informational distortion or legal disrespect. This subjectivity is justified by the increasing complexity of the accounting context and scope, which means that accounting standards are forced to be more general and flexible. On the one hand, the existence of a dynamic set of principles, rules and criteria that reduce unintentional or deliberate distortions in terms of amount and quality of information to be provided to interested parties is crucial. On the other hand, the greater the scope, the more general and flexible will the established norms have to be. Thus, accounting standards and concepts are subject to different interpretations, arising from the various sensitivities and opinions of those who use or apply them, and from the differing information needs of stakeholders. It is the generality and flexibility of regulations that provide opportunities for the so-called creative accounting which, however, can be dissociated from any irregularities in the legal level.

Therefore, accounting scandals continue to occur in the present days in many areas and countries. The current financial crisis in many countries is highlighted, such as Portugal, Greece and Ireland, where central, regional and local administrations are involved for creating artificial values that generated untrue values. They are a common denominator for all measurement issues associated with accounting manipulation which, once performed, constitute, according to Nogueira (2012), schemes to take from the future to live better in the present. Whether these schemes are illusory or not of real happiness, they refer almost instantly to the raising of ethical questions and to the relationship of ethics and accounting. The current crisis in most European countries is thus related, at macro and micro economic and social levels, to the economic crisis, which in turn is based on a crisis of ethical values. These scenarios have contributed and may continue to contribute to the increase of creative accounting practices, often associated with financial reporting fraud. Thus creative accounting is at a crossroads between illegality or fraud and truly correct and ethical business practices based on ethical behaviour, where it is difficult to establish the boundaries.

\section{Creative Accounting}

Accounting scandals based on fraudulent and accounting manipulation, which led to the promulgation of the famous Hammurabi code, have been known since 1720 b.C. in ancient Mesopotamia and have been occurring to this day in all areas and countries. In this context, these issues have been the subject of investigation and discussion, as well as accounting manipulation and have generated some controversy in several countries such as the USA, United Kingdom, Canada, Australia and France (Stolowy \& Breton, 2004; Jones, 2011). Copeland (1968) defined accounting manipulation as the ability to increase or decrease the result to the intended values. However, accounting manipulation has a broader scope than that presented by Copeland. It includes manipulations at the results level, as presented by Barnea, Ronen and Sadan 
(1975, 1976) and Ronen and Sadan (1975) and at the balance sheet items, although the latter are less documented in the literature (Black, Sellers, \& Manly, 1998).

As the result is most used measure by stakeholders in the assessment of economic performance and decision making, and being composed of income and expenses, it is likely that it is in the statements that show them that there is more risk of manipulation. Although information about performance is mainly drawn from the income statement, in accounting terms, finding a consensual definition of the concept of earnings is a complicated problem. The differences are mainly related to unrecognized assets and liabilities and to the rules stipulating late recognition of changes in their value. These are enhanced by the fact that there are accounting practices that allow inconsistencies in the measurement of results, the absence of a theoretical basis for their calculation and disclosure, and the lack of consensus on the measurement of their elements and the accounting policies to be transposed (Hendriksen \& Breda, 1992). There are elements that, although affecting the company's performance over time, are not recognized in profit or loss and there are also those that are affected by judgments, estimates and valuation criteria. At the literature level, there is disagreement about the gains and losses to be included in the income statement (Johnson, Reither, \& Swieringa, 1995; Revsine, Collins, \& Johson, 1999). There are balance sheet proponents who see it as a way of increasing liquidity in the bottom line, and income statement defenders who view the balance sheet as a list of elements that are left after offsetting income and expenses (Belkaoui, 1997).

Thus, accounting manipulation practices have become more important and complex over time, but have in common the objective of maximizing, minimizing or blurring income, that is, making them more or less constant over successive periods, and then be a form of constituting hidden reserves (Moore, 1973). They also share a common conception of accounting as a tool that supports company strategy and reduces perceived risk (Stolowy \& Breton, 2004). This increase in complexity is largely due to the professionalization of top management in companies, that is, it is delivered to professional managers hired for this purpose, separating the owners of the companies and their managers. In this regard, Griffiths (1988) states that all UK companies manipulate their results. They are based on books that have been more or less delicately retouched, use tricks without breaking the rules of the game, legitimate, in the author's opinion, simply creative accounting. However, in order to affect income and expense accounts, it is sometimes necessary to affect balance sheet accounts that have an impact on income. On the other hand, companies may be interested in manipulating the debt ratio, which is necessary for balance sheet accounts.

In this context, authors such as Stolowy and Breton (2004) suggest a theoretical framework for understanding accounting manipulation practices. Its fundamental principle is based on the fact that financial reporting aims to reduce financing costs of corporate projects, and this reduction is related to investors' perception of corporate risk, calculated based on measures of variation in earnings per share and in the relationship between liabilities and equity. Earnings per share may be modified by increasing or decreasing income or expenses or by premeditated transaction manipulation designed for a particular intended accounting treatment. At the literature level, it is also argued that managers' motivation for accounting manipulation and the timing of accounting manipulation should also be taken into account, in addition to accounting manipulation at the level of interpretations of accounting regulation. Manipulation may also occur because generally accepted accounting principles (GAAP) may not provide a specific accounting treatment for a given situation and also at the level of transactions, which may be strategically chosen to allow a certain desired accounting treatment. Figure 1 presents the main objective, affected measures and mechanisms associated with accounting manipulation.

In short, corporate risk is perceived as a function of measures that underlie income, assets, liabilities and equity. Given that these encompass a large set of assumptions, originated by the various accounting criteria, estimates and judgments, accounting manipulation may exist, with a view to changing the interpretation of accounting regulations, as the GAAP does not reach the situation or through the transactions. Basically, and according to Jones (2011, p. 550), the definitions of creative accounting fall into one of two perspectives. The first, called wide definition and adopted by Mulford Comiskey (2002, p. 15) in the USA. 
According to (Mulford \& Comiskey, 2002) "Any and all steps used to play the financial numbers game, including the aggressive choice and application of accounting principles, both within and beyond the boundaries of generally accepted accounting principles, and fraudulent financial reporting. Also included are steps taken towards earnings management and income smoothing".

The second view is called narrower definition and it is being adopted in the United Kingdom, which according to the Chartered Institute of Management Accounting (2000) is defined as "a form of accounting which, while complying with all regulations, nevertheless gives a biased impression (generally favorable) of the company's performance".

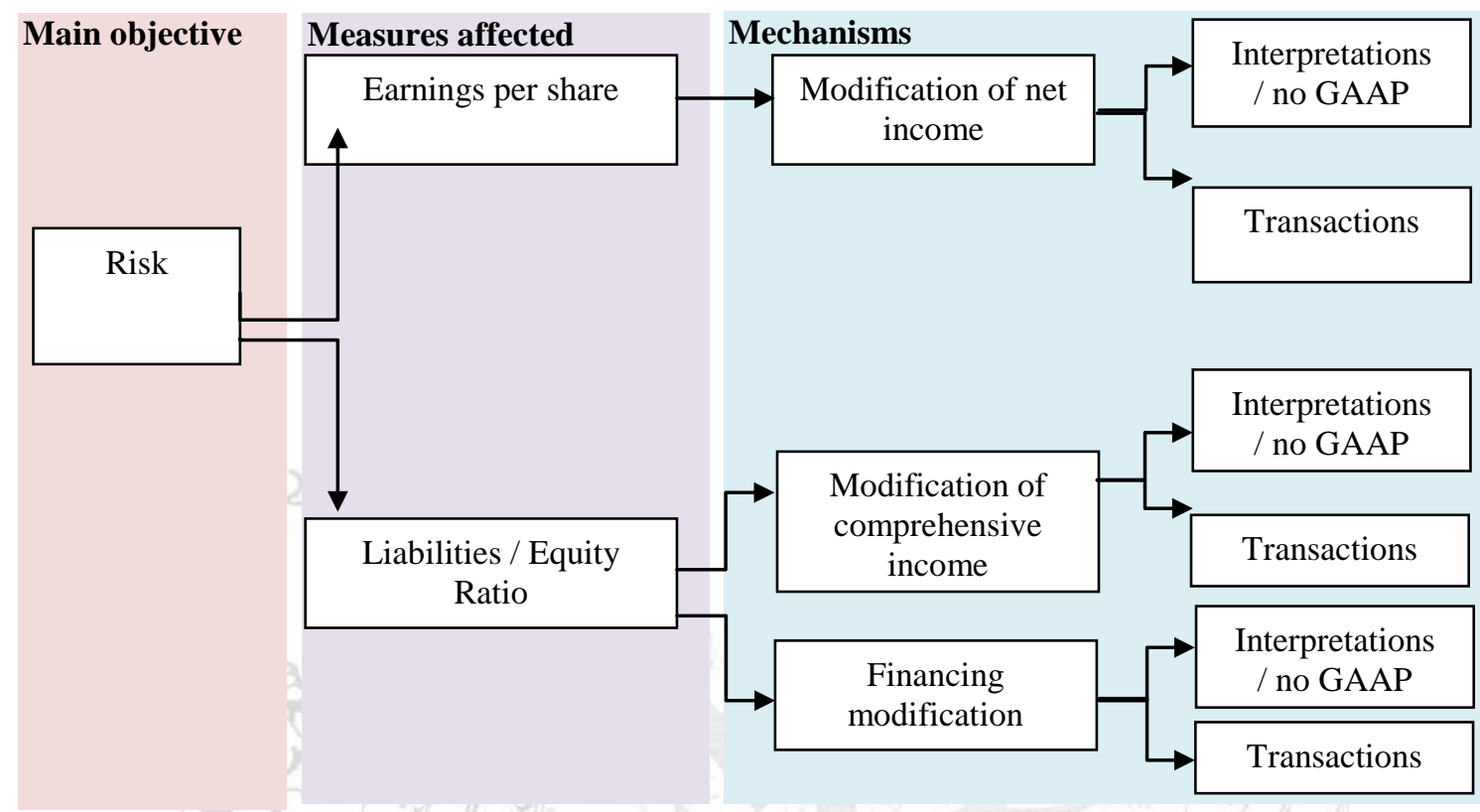

Figure 1: Objectives, measures and mechanisms of accounting manipulation. Source: Adapted from Stolowy and Breton (2004).

Thus the definitions of creative accounting that are based on the most limited view consider it to be a tool that utilizes flexibility within the legal system and excludes any fraud, while definitions that approach the American view explain creative accounting as including fraud.

The definition of creative accounting adopted in this investigation is close to the UK view, excluding fraud from it. On the other hand, it is based on the definition adopted by Jones (2011, p. 575) "using the flexibility in accounting within the regulatory framework to manage the measurement and presentation of accounts so that they give primacy to the interests of the preparers not the users". Thus, companies using creative accounting practices are considered to take advantage of the flexibility of accounting standards to present financial information in accordance with the interests of, for example, the preparers of the financial statements, to the detriment of other users of that information, without however, committing illegalities or fraud.

Financial reporting is recognized by many accounting systems as a reliable picture of the reality it intends to represent and that its purpose is to convey this picture in a true and appropriate manner, leading to true or fair financial statements. In contrast, creative accounting privileges the interests of financial statement preparers. This possibility is real due to the flexibility in the regulations. However, this flexibility is necessary, given the specificities of the companies' businesses and different environments, so that they provide the appropriate financial information, faithful and true to other stakeholders. It is because of the existence of information asymmetries between the internal and external users of the financial statements 
and some limitations in accounting that may give rise to different interpretations, depending on the opinion or sensitivity of those who use them, that this flexibility can serve creative accounting.

Figure 2 shows the relationship between the lack of flexibility and the flexibility that allows to provide a true and faithful image, creative or fraudulent.
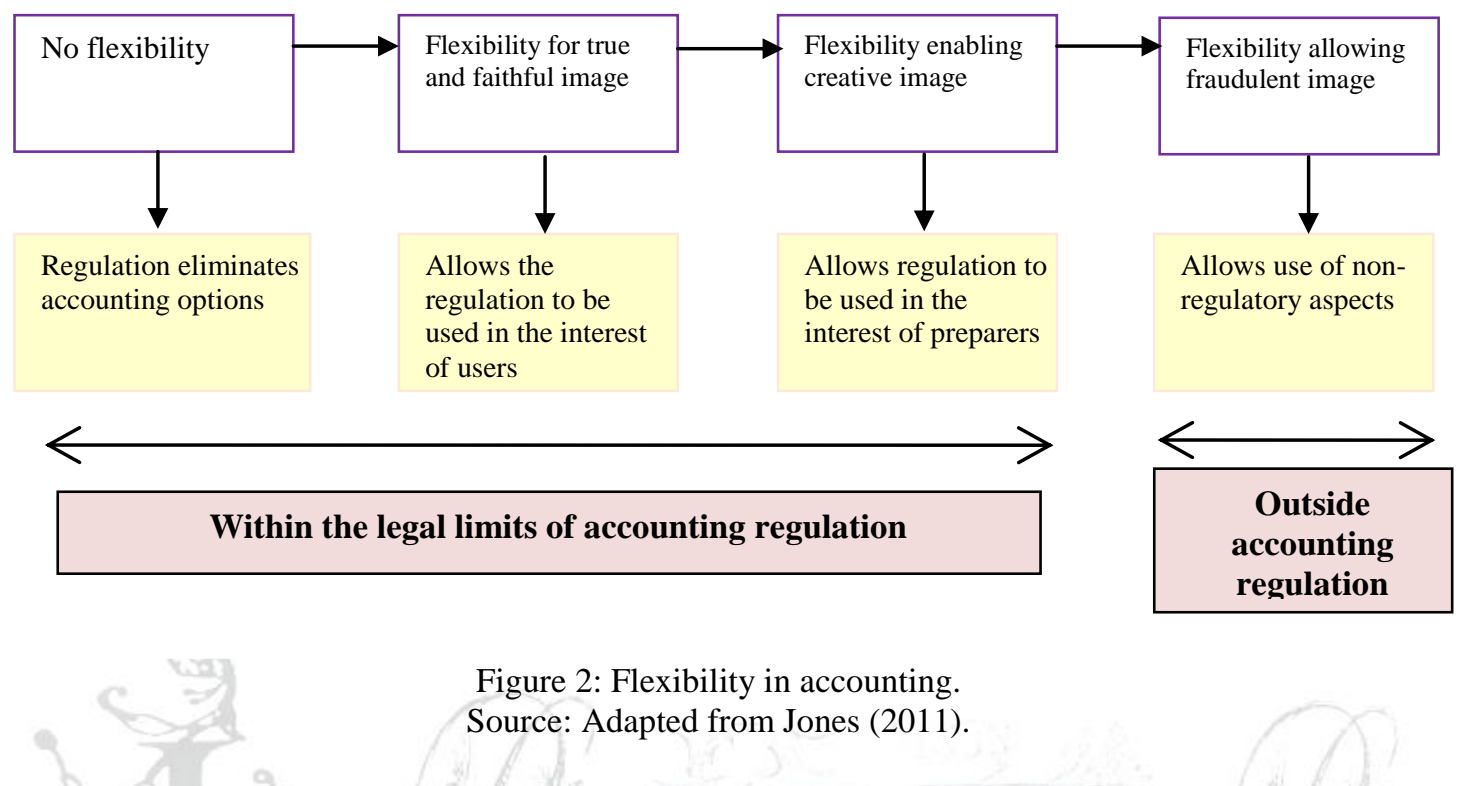

Figure 2: Flexibility in accounting.

Source: Adapted from Jones (2011).

In a situation of complete lack of flexibility in accounting regulation there will be no creative accounting. However, it will also not allow the true and fair representation of reality, preventing the objective of the financial statements from providing faithful and truthful information to other stakeholders when making their economic decisions, from being met. Moreover, the flexibility of accounting standards required to present the true and appropriate image of companies allows managers to adopt creative accounting practices without committing any fraud within accounting regulations. However, the meaning of accounting may be questioned, given that its purpose is that the financial information presented by an entity is the true and appropriate picture. When managers or accountants go outside the bounds of accounting regulation they may be falling into accounting fraud and presenting a false financial report.

The research branches associated with accounting manipulation are, in the literature, often transversal to several categories, such as earnings management, earnings manipulation, aggressive accounting, conservative accounting, big bath accounting and impression management. Figure 3 presents, considering the literature, the main lines of research associated with accounting manipulation. The term creative accounting it is often used in the literature to encompass the whole area called earnings management and creative accounting. Smith (1992) states that it is an inappropriate practice used by companies to present non-real economic-financial growth indicators. Another author, Naser (1993), considers creative accounting to be the result of the transformation of accounting values from what they really are to what those who make them claim to be, taking advantage of the facilities that accounting principles and standards provide, or even ignoring them. Jameson (1998) states that this is a process of using accounting principles and standards, which consists in interpreting decision-making legislation, based on existing flexibility and omissions, to make financial statements look different from what is established in these principles and norms. Thus creating opportunities for manipulation that, when tapped by less scrupulous (or more dependent) professionals, give rise to creative accounting. According to Lang (1998) the term creative accounting describes the process by which knowledge of accounting principles and standards is used to manipulate the values of financial statements, and is in fact a euphemism used to avoid reference to these practices by their true values. Names such as accounting gimmicks, accounting manipulations or 
even, ultimately, accounting frauds. According to Saludas (1999) creative accounting is a kind of art where great accounting artists take advantage of the facilities offered by regulatory rigor to create a plot that allows them to mirror the desired fiscal or corporate image. Gadea and Callao (1999) in Saludas (1999) argue that this consists in taking advantage of the possibilities offered by accounting standards, such as opportunities for subjectivity, choice or legal voids, with a view to financially reporting a desired image of the company, not necessarily real. Mulford and Comiskey (2002) define creative accounting as the actual change in financial statements using the various segments of accounting manipulation as earnings management, earnings smoothing, big bath accounting and aggressive accounting.

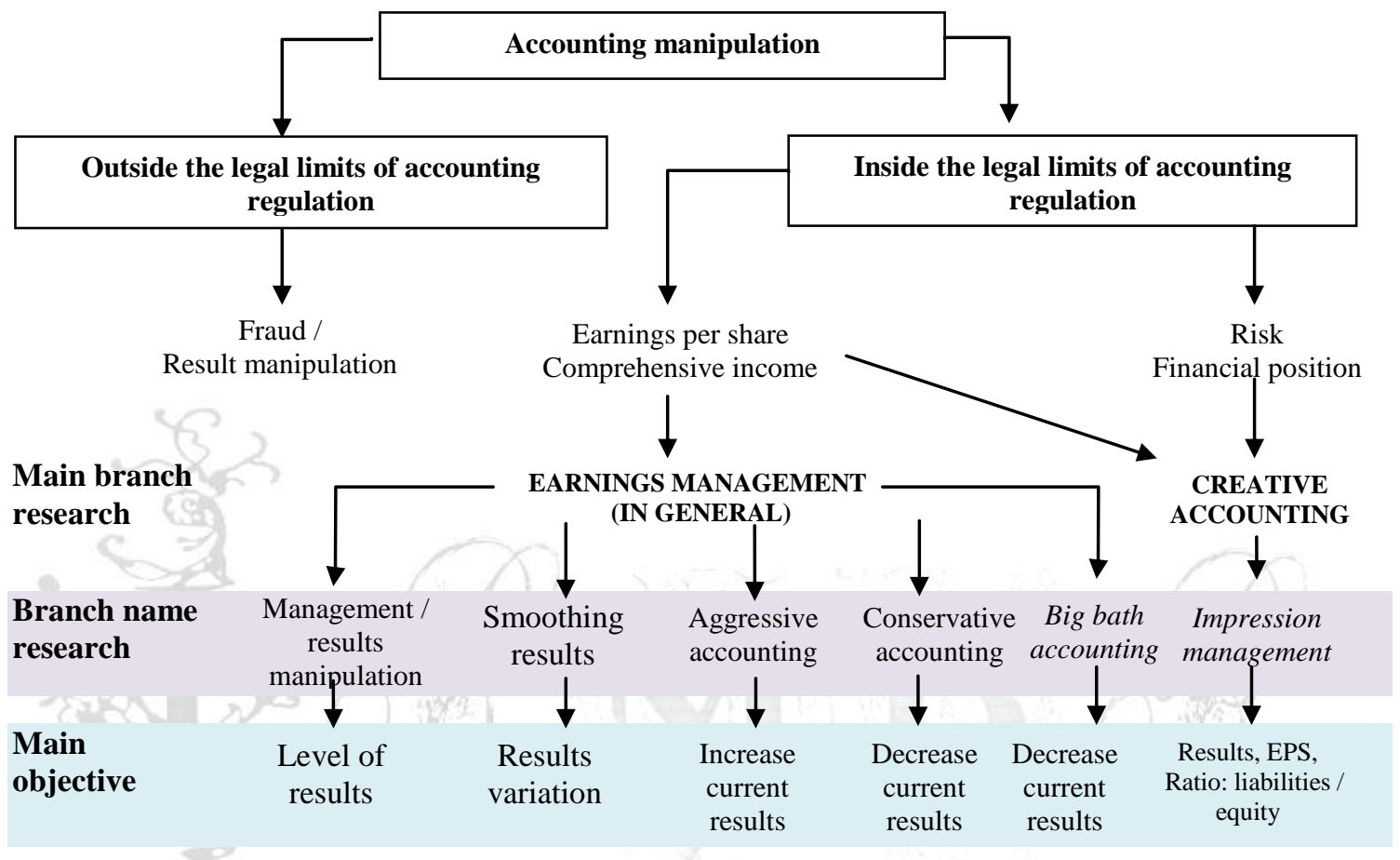

Figure 3: Investigation on accounting manipulation

According to the authors Stolowy and Breton (2004), the term accounting manipulation appears associated, in addition to creative accounting, with earnings management, earnings smoothing and big bath accounting. However, this is also considered to exist at the macro level when some financial statement preparers exert pressure and influence accounting standards-issuing bodies to develop rules targeting their interests (Gowthorpe \& Amat, 2005). For Sá (2010) creative accounting consists of reporting false information in order to show something that did not really happen, resulting from management measures, including the smoothing of results. According to Jones (2011) there is still a relationship between creative accounting and impression management. According to the author, impression management represents an attempt by management to give users, through financial reporting, the impression desired by managers. Although more related to aspects of presentation and voluntary disclosure, it includes creative accounting. In conclusion, in literature there is no consensual or exact definition of creative accounting, as it is always associated, on the one hand, with a kind of embellishment of the patrimonial reality of a company following the intentional manipulation of accounting data with the purpose of financial information presented convey the desired image. On the other hand, the absence of accounting standards that contribute to the adoption of essential creative practices has contributed to the very development of financial accounting. As a result, the risk of fraud has often increased in parallel with creativity for the development of acceptable accounting practices. Thus creative accounting is at a crossroads between illegality or fraud and truly correct and ethical business practices based on ethical behavior, up till now it is difficult to establish the boundaries. 
Figure 4 shows the positioning of creative accounting against fraud to business practices in accordance with accounting regulation.

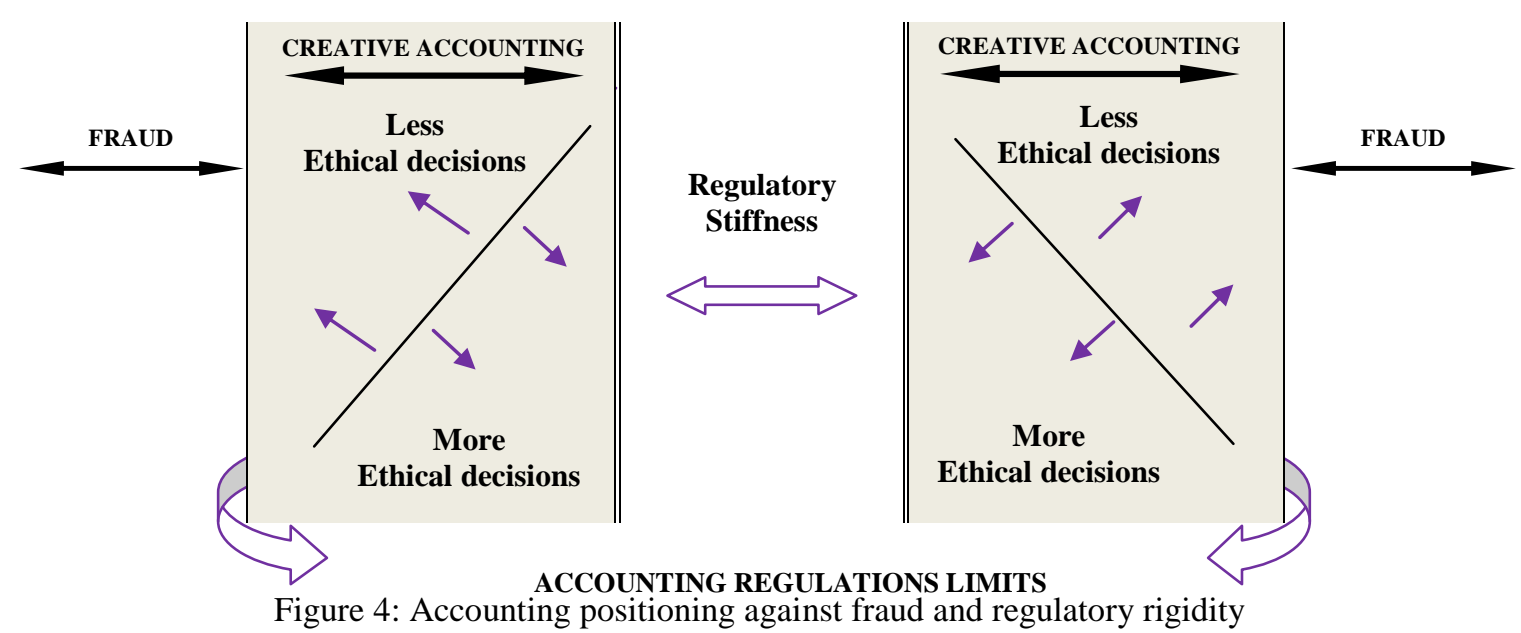

In business ethics at the individual level, it comprises the behavior and actions of individuals in organizations. It is important to emphasize the principles of professional ethics that lead to ethical decisions based on fundamental principles such as integrity, objectivity, professional competence and technical confidentiality and professional behavior, pointed by Kaplan (2010) and apply them to accounting and finance. Consequently, it seems obvious that creative accounting is now strongly associated with decisions that address ethical accounting issues.

\section{Empirical Study}

\section{Objective and Hypotheses}

In order to investigate the association between creative accounting and ethics, it was analyzed the level of discomfort in creative accounting decisions through accountants' perceptions of creative accounting practices. Moreover, the following hypotheses were tested, relating ethical discomfort in the attitude of accountants towards decisions about creative accounting practices:

HP1: Accountants differentiate, in terms of ethical discomfort, creative accounting practices from fraudulent accounting practices;

HP2: Accountants present different levels of ethical discomfort towards creative accounting practices.

\section{Methodology}

From the literature review, the fundamental and specific aspects related to the link between CSR and ethics were identified. A survey was carried out and the statistical treatment of data was performed using IBM SPSS Statistics (exploratory analysis of information) and AMOS (Analysis of Moment Structures) was used in the framework of structural equation modeling. The first part of the questionnaire includes questions related to demographic factors in order to characterize the employer in ethical terms. The second part of the survey includes 21 questions related to decision-making on aspects of corporate social responsibility. In this part of the survey qualitative variables were used a numerical scale with 7 categories, indicating: the degree of agreement with the statements in total disagreement; I strongly disagree; I disagree a little; neither agree nor disagree; I agree little; I largely agree; and totally agree. 


\section{Sample}

The study population consists of the $\sim 300$ accountants of the 55 companies listed on the Euronext Lisbon. Regarding the total universe, the financial companies were removed, due to their accounting characteristics and particularities, in order to ensure comparability of data. Therefore, the final sample consists of $\mathrm{N}=37$ companies. From the universe, a total of 168 accountants were contacted for this study and 100 valid answers were obtained, which corresponds to a sampling error of $\pm 8 \%$. The respondents are then characterized in Figure 5. It is found that the reporting accountants have on average 10 to 20 years of professional experience in accounting and that they are mostly between 30 and 45 years old. Male accountants account for $51 \%$ of respondents, showing that most are Certified Accountants. Regarding the literary level, it can be observed that most respondents have a degree, with a weight of about $81 \%$ of the total respondents.

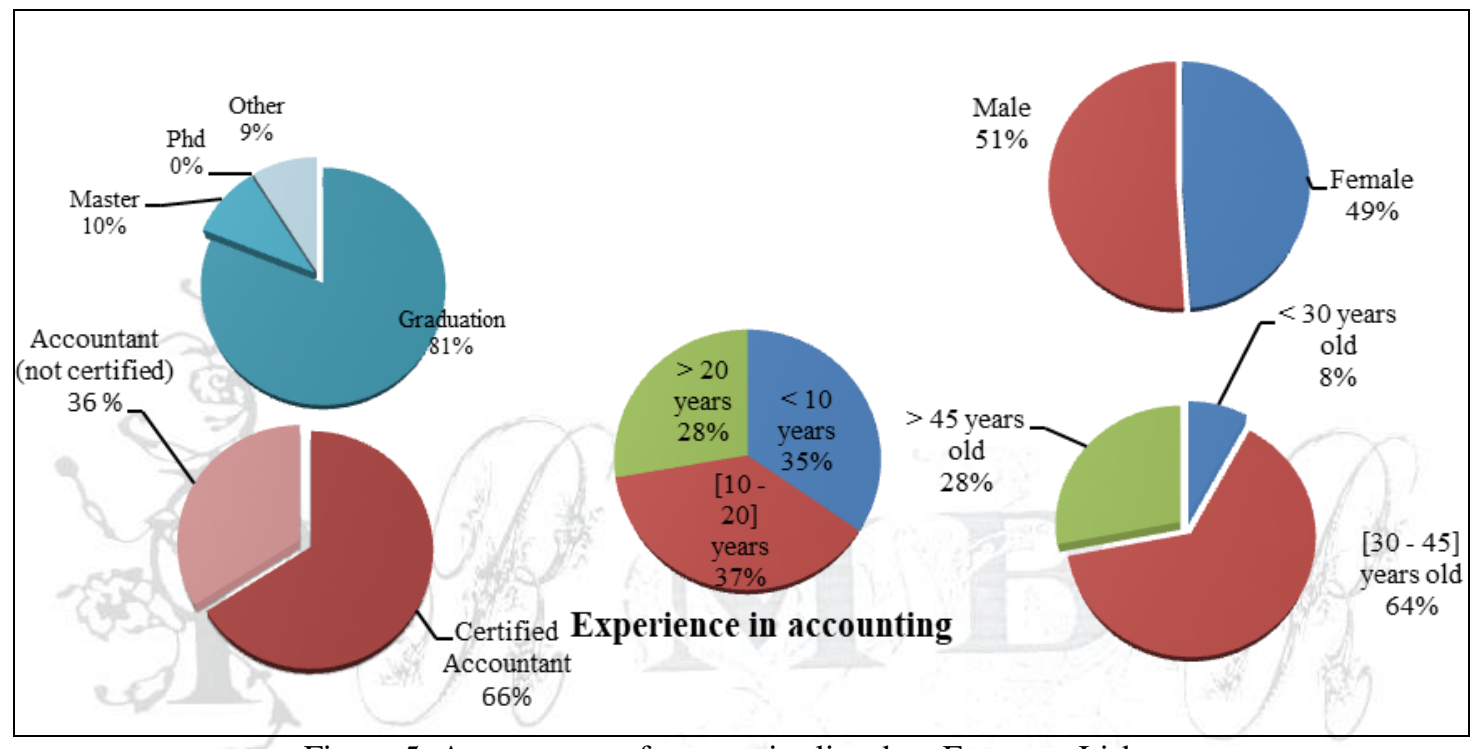

Figure 5: Accountants of companies listed on Euronext Lisbon

\section{Results}

To analyze the dimensions associated with creative accounting, it was analyzed a set of items collected for this purpose, in order to validate whether the sample data matrix was related to the previously sustained theoretical framework of creative accounting. After the analysis and validation of the items (distribution, verification of missing values, among others) in order to create latent dimensions that would explain creative accounting to us, a Principal Component Analysis (PCA) was applied to the data matrix. This technique seeks to reduce the number of items to describe something and in our particular case detect the underlying dimensionality of the data matrix. This analysis allows summarizing and identifying dimensions that allow the data to be described according to a smaller number of concepts. To perform this analysis the data must meet certain requirements, namely that the input variables are metric or treated as such and it is desirable to have some level of multicollinearity, the assessment of this requirement is made through the correlation matrix, the Kaiser-Meyer-Olkin (KMO) statistic and Bartlett Test. In this line of reasoning, the KMO statistic tests whether partial correlations between variables are reduced and indicates the variance proportion of the variables that is common variance. Generally speaking, KMO values close to 0.6 would be considered 'adequate', while values close to 0.7 would be considered 'good' and above 0.8 as 'excellent'. Moreover, Bartlett's Sphericity test tests the hypothesis of the variables in the analysis form an identity matrix. Such a matrix would indicate that the variables are uncorrelated (i.e. all values outside the diagonal of the correlation matrix would be close to zero) and the data would be inadequate for analysis. Table 1 
shows the value obtained for the KMO statistic and the significance of the Bartlett test, with a KMO of 0.79 indicating that the data are adequate for analysis. This fact is further reinforced by Bartlett's Sphericity test which accepts the hypothesis that the data does not form an identity matrix, according to its hypothesis:

Ho: The correlation matrix in the population is an identity matrix;

Ha: The correlation matrix in the population is not an identity matrix.

Table 1: KMO Bartlett Test

\begin{tabular}{|llr|}
\hline Kaiser-Meyer-Olkin Measure of Sampling Adequacy. & 0,793 \\
Bartlett's Test of Sphericity & Approx. Chi-Square & 996,457 \\
& Df & 190 \\
& Sig. & 0,000 \\
\hline
\end{tabular}

Thus, with P-value $=0.000(<0.05)$ Ho is rejected and it is accepted that the correlation matrix is not an identity matrix, so it can be concluded that there are significant correlations between the original and that it is possible to find dimensions that explain the existing correlations.

Table 2: Communalities

\begin{tabular}{|c|c|c|}
\hline Variables & Initial & Extraction \\
\hline $\begin{array}{l}\text { 1.1 Postponement of equipment maintenance from December to March to avoid } \\
\text { damaging the stock market price. }\end{array}$ & 1,000 & 0,728 \\
\hline $\begin{array}{l}\text { 1.2 Recognition of expenditures in the current year, which were only planned for } \\
\text { next year, because profit is above forecast. }\end{array}$ & 1,000 & 0,674 \\
\hline $\begin{array}{l}\text { 1.3 Postponement of spending specialization from March to April to achieve } \\
\text { quarterly targets. }\end{array}$ & 1,000 & 0,668 \\
\hline 1.4 Recognition of expenses with training activities as intangible assets. & 1,000 & 0,736 \\
\hline $\begin{array}{l}\text { 1.5 Recognition of actuarial gains / losses by opting for the method to obtain the } \\
\text { desired benchmarks. }\end{array}$ & 1,000 & 0,539 \\
\hline 1.6 Recognition of expenses related with non-realized overtime work. & 1,000 & 0,569 \\
\hline 1.7 Sale of superfluous goods at the end of the year for recognition of gains. & 1,000 & 0,478 \\
\hline 1.8 Recognition of revenue from services billed and charged but not yet provided. & 1,000 & 0,669 \\
\hline 1.9 Recognition of year-end sales associated with a repurchase agreement. & 1,000 & 0,674 \\
\hline 1.10Recognition of investment grant fully as income at the time of award. & 1,000 & 0,747 \\
\hline 1.11 Inventory measurement opting for the most favorable costing formula. & 1,000 & 0,812 \\
\hline $\begin{array}{l}\text { 1.12 Asset valuation using discount rates in the present value calculation, opting for } \\
\text { the most favorable technique. }\end{array}$ & 1,000 & 0,749 \\
\hline $\begin{array}{l}\text { 1.13Reclassification of tangible fixed assets related to the production process to } \\
\text { current assets held for sale to avoid depreciation. }\end{array}$ & 1,000 & 0,599 \\
\hline $\begin{array}{l}\text { 1.14Asset depreciation ignoring the separation of parts whose cost is significant in } \\
\text { relation to the total cost of the item. }\end{array}$ & 1,000 & 0,557 \\
\hline $\begin{array}{l}\text { 1.16Classification of current liabilities as non-current liabilities in order to favor the } \\
\text { entity's ratios. }\end{array}$ & 1,000 & 0,591 \\
\hline 1.17Change guarantee rates to recognize lower amounts of provisions. & 1,000 & 0,679 \\
\hline $\begin{array}{l}\text { 1.18 Non-recognition, at the end of the year, of the obligation (liability) regarding the } \\
\text { distribution, previously announced, of part of the profits to employees. }\end{array}$ & 1,000 & 0,688 \\
\hline $\begin{array}{l}\text { 1.19Not disclosing a liability for asset decommissioning because it is not possible to } \\
\text { establish a reasonable and reliable estimate. }\end{array}$ & 1,000 & 0,760 \\
\hline $\begin{array}{l}\text { 1.20Non-disclosure of an unrecognized contingent loss whose probability of } \\
\text { occurrence is more than remote. }\end{array}$ & 1,000 & 0,865 \\
\hline 1.21Disclosure of voluntary information to increase company market value. & 1,000 & 0,720 \\
\hline
\end{tabular}


Table 2 presents the communality. These represent the variance ratio of the variable explained by the factors (here main components). As initially as many components as variables are adjusted, the commonalities in the first column (Initial) are usually 1. They are relevant when a solution is reached (Extraction column), here the commonalities are below 1 and they measure the percentage of variance in each variable captured by the components. Any variables with reduced communalities (e.g. 0.2 or less) will have little in common with other variables, and are not explained by the components (or factors), nor do they contribute to their definition.

In order to have a better interpretation, the Varimax rotation was performed, which is an orthogonal method proposed by Kaiser, where for each main component there are only some significant weights and all the others are close to zero. In order to maximize the variation between the weights of each dimension, obtained through an iterative process of maximizing a quadratic function of these weights, the differences between the contributions of the variables are maximized, increasing the weight of the ones that contribute the most to the solution formation and reducing the weight of the ones that least contribute. Thus, the distribution of total variance explained by the various dimensions is verified, without affecting the communality.

Table 3: Total variance explained from Accounting Manipulation.

\begin{tabular}{|c|c|c|c|c|c|c|c|c|c|}
\hline \multirow{4}{*}{$\begin{array}{l}\text { Compo- } \\
\text { nent }\end{array}$} & \multicolumn{3}{|c|}{ Values } & \multicolumn{3}{|c|}{ Extraction } & \multicolumn{3}{|c|}{ Rotation } \\
\hline & & & $\%$ & & & $\%$ & & & $\%$ \\
\hline & & $\%$ de & Accumulat & & $\% \mathrm{de}$ & Accumula & & $\%$ de & Accumula \\
\hline & Total & Variance & ed & Total & Variance & ted & Total & Variance & ted \\
\hline 1 & 6,694 & 33,470 & 33,470 & 6,694 & 33,470 & 33,470 & 3,807 & 19,033 & 19,033 \\
\hline 2 & 2,261 & 11,307 & 44,777 & 2,261 & 11,307 & 44,777 & 3,020 & 15,100 & 34,133 \\
\hline 3 & 1,952 & 9,762 & 54,539 & 1,952 & 9,762 & 54,539 & 2,508 & 12,538 & 46,671 \\
\hline 4 & 1,552 & 7,758 & 62,297 & 1,552 & 7,758 & 62,297 & 2,337 & 11,686 & 58,357 \\
\hline 5 & 1,042 & 5,210 & 67,507 & 1,042 & 5,210 & 67,507 & 1,830 & 9,150 & 67,507 \\
\hline 6 & 0,847 & 4,236 & 71,743 & 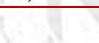 & & & & & \\
\hline 7 & 0,805 & 4,026 & 75,769 & & & & & & \\
\hline 8 & 0,707 & 3,533 & 79,302 & & & & & & \\
\hline 9 & 0,631 & 3,156 & 82,458 & & & & & & \\
\hline 10 & 0,503 & 2,516 & 84,975 & & & & & & \\
\hline 11 & 0,468 & 2,338 & 87,313 & & & & & & \\
\hline 12 & 0,439 & 2,195 & 89,508 & & & & & & \\
\hline 13 & 0,393 & 1,965 & 91,473 & & & & & & \\
\hline 14 & 0,353 & 1,764 & 93,236 & & & & & & \\
\hline 15 & 0,333 & 1,666 & 94,902 & & & & & & \\
\hline 16 & 0,285 & 1,426 & 96,328 & & & & & & \\
\hline 17 & 0,260 & 1,298 & 97,626 & & & & & & \\
\hline 18 & 0,214 & 1,069 & 98,695 & & & & & & \\
\hline 19 & 0,137 & 0,687 & 99,383 & & & & & & \\
\hline 20 & 0,123 & 0,617 & 100,000 & & & & & & \\
\hline
\end{tabular}

Table 3 presents the 20 indicators used, the percentage of explained variance and the cumulative explained variance of the Accounting Manipulation. It can be observed that a five-dimensional solution was found that explains about $67.5 \%$ of the total explained variance of Accounting Manipulation. This value is considered sufficient, since the total variance explained by the retained factors must be between $70 \%$ and $80 \%$ (Reis, 2001). For cutting decision and choice of this number it was applied the Kaiser criterion, which excluded the components whose eigenvalues are less than one. 
Figure 6 shows the number of extracted components in scree plot, which reinforces the choice of a 5dimensional solution. When the percentage of variance explained by each component is reduced, the curve becomes almost parallel to the abscissa axis, indicating that all other components whose eigenvalue is less than one should be excluded.

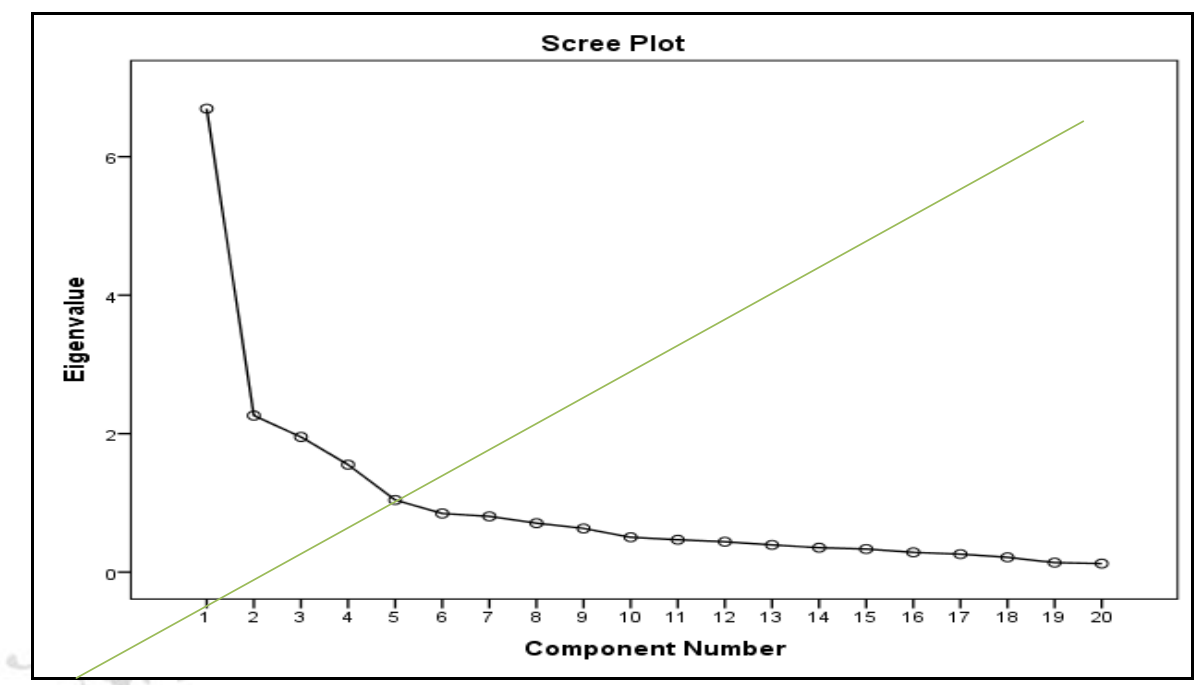

Figure 6: Result of the Scree plot.

Table 4 presents the manipulation practices that constitute each main component (extracted dimensions). It can be seen that the first component, which it was called Fraud Practices, shows that accountants identify manipulation practices that are closer to fraud and that violate accounting and financial reporting standards. The second component, the Most Creative and Less Ethical Practices dimension, includes creative accounting practices identified as less ethically legitimate. The third component, Less Creative and More Ethical Practices dimension, includes less fraudulent and more ethical identified creative accounting practices. The fourth dimension encompasses Creative Practices in Disclosure, associated with the voluntary disclosure, and the fifth dimension, named Creative Practices in Profit, considers important creative accounting practices that enable the increase or decrease in net income of the period when approaching reporting date.

Table 4: Rotated component matrix (1/2).

\begin{tabular}{|c|c|c|c|c|c|}
\hline \multirow{2}{*}{ Manipulation practices } & \multicolumn{5}{|c|}{ Component } \\
\hline & 1 & 2 & 3 & 4 & 5 \\
\hline Fraud Practices & & & & & \\
\hline $\begin{array}{l}\text { 1.10 Recognition of investment grant fully as income in the } \\
\text { moment of award. }\end{array}$ & 0,802 & & & & \\
\hline $\begin{array}{l}\text { 1.4 Recognition of expenses with training activities as } \\
\text { intangible assets. }\end{array}$ & 0,796 & & & & \\
\hline $\begin{array}{l}1.9 \text { Recognition of year-end sales associated with a repurchase } \\
\text { agreement. }\end{array}$ & 0,716 & & & & \\
\hline $\begin{array}{l}\text { 1.8 Recognition of revenue from services billed and charged but } \\
\text { not yet provided. }\end{array}$ & 0,608 & & 0,444 & & \\
\hline 1.6 Recognition of expenses related with non-realized overtime & 0,580 & 0,365 & & & \\
\hline $\begin{array}{l}1.13 \text { Reclassification of tangible fixed assets related to the } \\
\text { production process to current assets held for sale to avoid }\end{array}$ & 0,576 & 0,495 & & & \\
\hline
\end{tabular}


Table 4: Rotated component matrix (2/2).

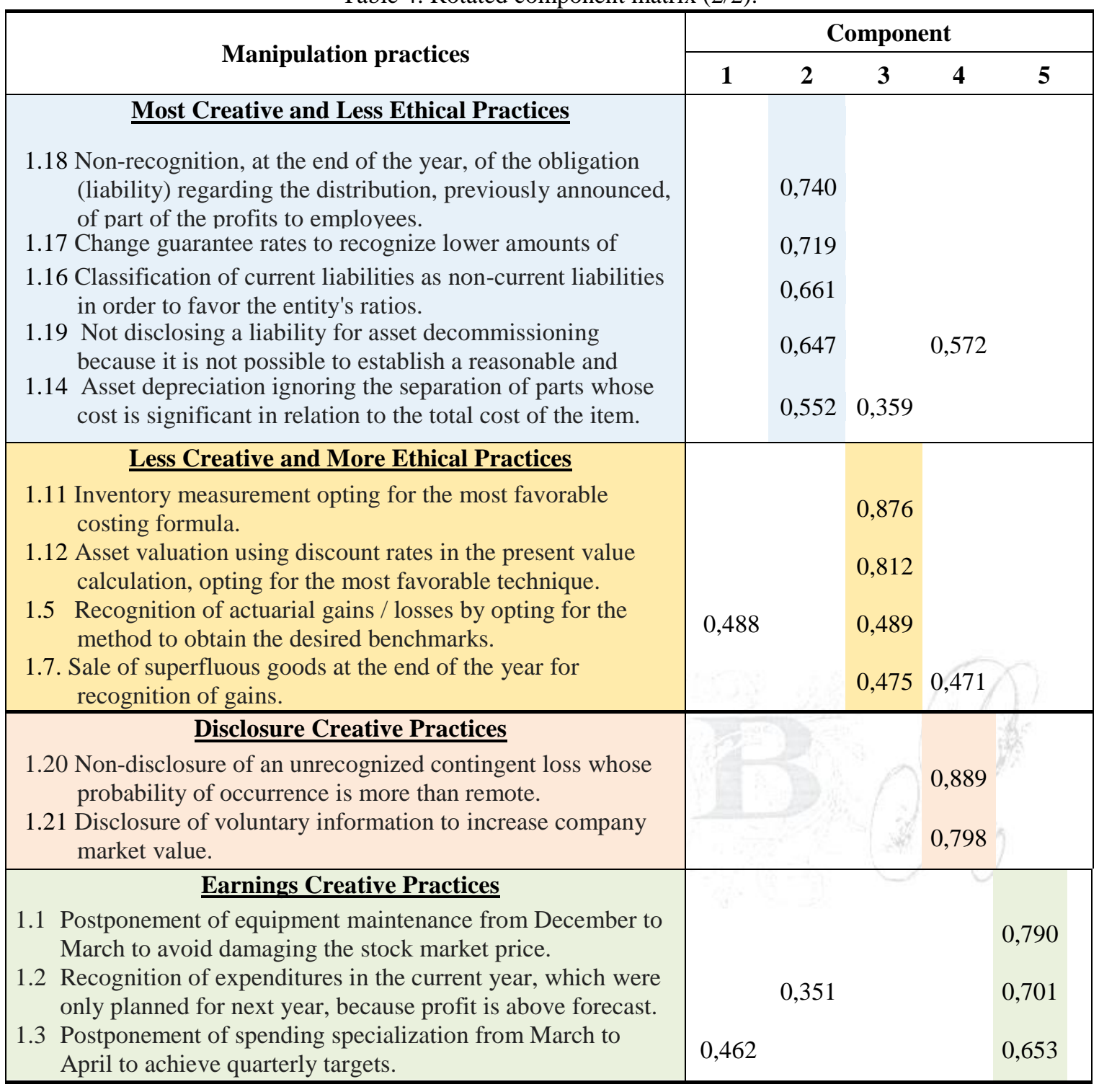

Cronbach's alpha test was also performed to test and validate the internal consistency of the five dimensions found. In turn, regarding the item correlation matrix, the value of the corrected item - total correlation indicator should be taken into account, and if the value of the item is less than 0.3 (Hair et al., 2010) will be evidence that the item is not consistent with the rest of the scale as a whole and may be measuring a different construct. The effect of any deletion of each item on the alpha value of the scale will also be examined. Due to the fact that some of the criteria were considered sufficient, a confirmatory factor analysis was performed on the dimensions found in order to validate their structure. In addition, it is good practice to perform a set of validations on the dimensions or constructs achieved. Thus, it was proceeded an evaluation of the dimensionality of the measurement scales of the five dimensions, according to the structural equation modeling suggested by Hair et al. (1998) that, besides allowing the evaluation of competing models and the development of new models, it allows the confirmation of models. By including and measuring constructs in the research model, the nature of the relationships between the multidimensional construct and its dimensions is clarified, and it is strongly recommended that multiple 
adjustment indicators be used, as various adjustment statistics consider different adjustment aspects or concepts.

Table 5 shows Cronbach's alpha levels for the five dimensions. It can be concluded that they have good levels of internal consistency. The total of the 20 variables has a Cronbach's alpha level of 0.879 , which indicates high reliability.

Table 5: Cronbach's Alpha

\begin{tabular}{|rlrr|}
\hline Dimension & Designation & Cronbach's Alpha & No. of variables \\
\hline 1 & Fraud Practices & 0,868 & 6 \\
2 & Most Creative and Less Ethical Practices & 0,796 & 5 \\
3 & Less Creative and More Ethical Practices & 0,725 & 4 \\
4 & Disclosure Creative Practices & 0,759 & 2 \\
5 & Earnings Creative Practices & 0,649 & 3 \\
\hline & Total & 0,879 & 20 \\
\hline
\end{tabular}

Through confirmatory factor analysis some of the adjustment values were considered, including the Goodness of Fit Index (GFI), Adjusted Goodness of Fit Index (AGFI), Normed Fit Index (NFI) and Comparative Fit Index (CFI). For GFI and AGFI in the majority, researchers expect values between 0.90 and 0.95 . AGFI falls into the parsimony indicator category as it attempts to compensate for the varying degrees of complexity of the model. The index penalizes more complex models and favours those with a minimum number of free paths. Their values are often lower than GFI and in proportion to the complexity of the models. The NFI compares the fit of the model to that of a model for the same data where independence of the measured or observed variables would be assumed. In general, values between 0.90 and 0.95 are indicators of proper adjustment. The CFI is a test equivalent to NFI but takes into account the sample size. According to Thompson (2000) some researchers suggest that the CFI should be considered as the statistical test of choice. Figure 7 presents the confirmatory factor analysis of the five dimensions. The GFI, NFI, CFI, AGFI adjustment values are all within the expected values above 0.90 .
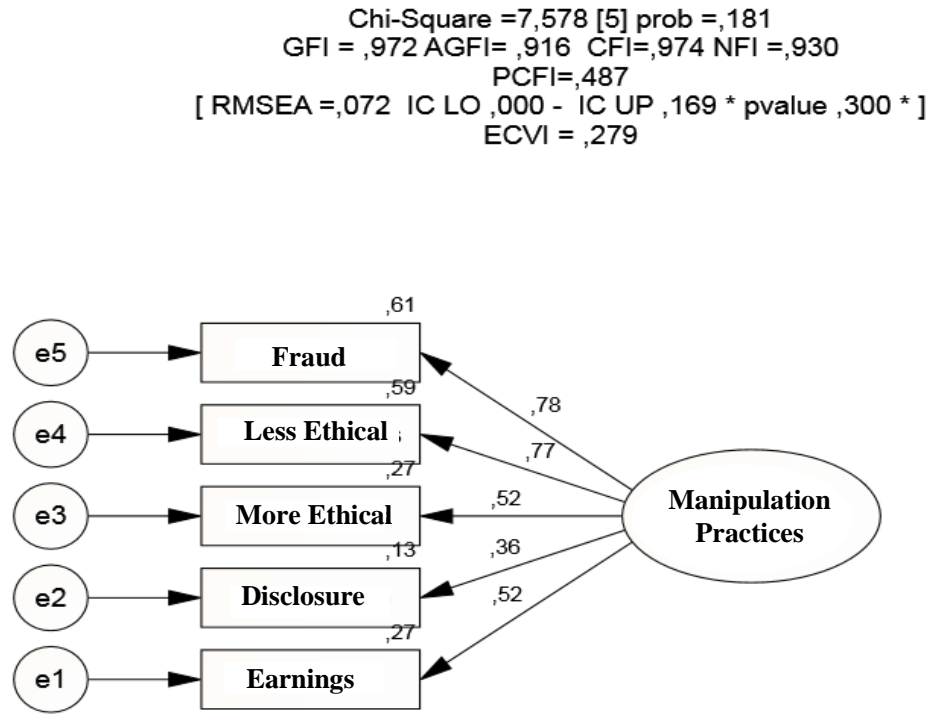

Figure 7: Confirmatory factor analysis of the five dimensions

Table 6 presents the statistics of the Fraud Practices dimension variables in relation to their internal consistency, ie Cronbach's Alpha if one item of the dimension variables is deleted. 
Table 6: Cronbach’s Alpha of the Fraud Practices Dimension

\begin{tabular}{|c|c|c|c|c|c|}
\hline & $\begin{array}{l}\quad \text { Fraud Practices Dimesion } \\
\text { - No. of items 6, Cronbach's Alpha 0,87 }\end{array}$ & $\begin{array}{r}\text { Scale } \\
\text { Mean } \\
\text { if Item } \\
\text { Deleted } \\
\end{array}$ & $\begin{array}{r}\text { Scale } \\
\text { Variance } \\
\text { if Item } \\
\text { Deleted }\end{array}$ & $\begin{array}{r}\text { Corrected } \\
\text { Item-Total } \\
\text { Correlation } \\
\end{array}$ & $\begin{array}{r}\text { Cronbach's } \\
\text { Alpha if } \\
\text { Item } \\
\text { Deleted } \\
\end{array}$ \\
\hline 1.4 & $\begin{array}{l}\text { Recognition of expenses with training activities as } \\
\text { intangible assets. }\end{array}$ & 11,05 & 19,987 & 0,677 & 0,843 \\
\hline 1.6 & $\begin{array}{l}\text { Recognition of expenses related with non-realized } \\
\text { overtime work }\end{array}$ & 11,77 & 21,896 & 0,599 & 0,856 \\
\hline 1.8 & $\begin{array}{l}\text { Recognition of revenue from services billed and } \\
\text { charged but not yet provided. }\end{array}$ & 11,32 & 20,806 & 0,660 & 0,846 \\
\hline 1.9 & $\begin{array}{l}\text { Recognition of year-end sales associated with a } \\
\text { repurchase agreement. }\end{array}$ & 10,99 & 19,889 & 0,727 & 0,834 \\
\hline 1.10 & $\begin{array}{l}\text { Recognition of investment grant fully as income in } \\
\text { the moment of award. }\end{array}$ & 11,07 & 20,268 & 0,673 & 0,844 \\
\hline 1.13 & $\begin{array}{l}\text { Reclassification of tangible fixed assets related to the } \\
\text { production process to current assets held for sale to } \\
\text { avoid depreciation. }\end{array}$ & 11,30 & 21,707 & 0,658 & 0,847 \\
\hline
\end{tabular}

The results reveal an internal consistency index, Cronbach's alpha 0.86, whose value is quite high. In terms of corrected item - total correlation corrected values range between a minimum of 0.59 and a maximum of 0.73. In terms of eventual improvement of the alpha index it makes no sense to eliminate any of the items analysed.

Table 7 presents the Most Creative and Less Ethical Practices dimension and Cronbach's alpha if one item of the dimension variables is deleted. The results reveal an internal consistency index, Cronbach's alpha, 0.79 , whose value is quite high. In terms of corrected item - total correlation corrected values range between a minimum of 0.53 and a maximum of 0.62 . In terms of eventual improvement of the alpha index it makes no sense to eliminate any of the items analysed.

Table 7: Cronbach's Alpha of the Most Creative and Less Ethical Practices Dimension

\begin{tabular}{|c|c|c|c|c|c|}
\hline & $\begin{array}{l}\text { Most Creative and Less Ethical Practices } \\
\text { No of items 5, } \frac{\text { dimension }}{\text { Cronbach's Alpha } 0,79}\end{array}$ & $\begin{array}{r}\text { Scale } \\
\text { Mean } \\
\text { if Item } \\
\text { Deleted }\end{array}$ & $\begin{array}{r}\text { Scale } \\
\text { Variance } \\
\text { if Item } \\
\text { Deleted }\end{array}$ & $\begin{array}{r}\text { Corrected } \\
\text { Item-Total } \\
\text { Correlation } \\
\end{array}$ & $\begin{array}{r}\text { Cronbach's } \\
\text { Alpha if } \\
\text { Item } \\
\text { Deleted }\end{array}$ \\
\hline 1.14 & $\begin{array}{l}\text { Asset depreciation ignoring the separation of parts } \\
\text { whose cost is significant in relation to the total cost of } \\
\text { the item. }\end{array}$ & 9,38 & 9,955 & 0,534 & 0,771 \\
\hline 1.16 & $\begin{array}{l}\text { Classification of current liabilities as non-current } \\
\text { liabilities in order to favor the entity's ratios.. }\end{array}$ & 9,51 & 9,485 & 0,624 & 0,743 \\
\hline 1.17 & $\begin{array}{l}\text { Change guarantee rates to recognize lower amounts } \\
\text { of provisions. }\end{array}$ & 9,65 & 10,048 & 0,594 & 0,754 \\
\hline 1.18 & $\begin{array}{l}\text { Non-recognition, at the end of the year, of the } \\
\text { obligation (liability) regarding the distribution, } \\
\text { previously announced, of part of the profits to } \\
\text { employees. }\end{array}$ & 9,92 & 9,893 & 0,560 & 0,763 \\
\hline 1.19 & $\begin{array}{l}\text { Not disclosing a liability for asset decommissioning } \\
\text { because it is not possible to establish a reasonable } \\
\text { and reliable estimate. }\end{array}$ & 8,98 & 8,787 & 0,590 & 0,757 \\
\hline
\end{tabular}

Figure 8 presents confirmatory factor analysis of the Fraud Practices and More Creative and Less Ethical Practices dimensions. The adjustment values GFI, NFI, CFI, AGFI are all within the expected values. 
According to this analysis, the adjustment of the data to a latent factorial structure is adequate according to the CFI index 0.99, as well as the fact that the items constituting it have effects between 0.62 and 0.77 for Fraud dimension and 0.60 to 0.74 for the Less Ethical and More Creative Practices dimension.

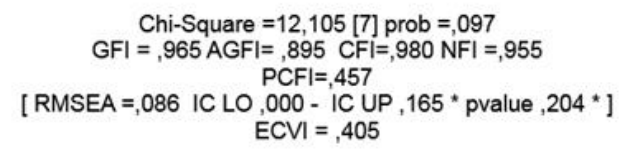

, $000-$ IC UP, $165^{*}$ pvalue, $\left.204 *\right]$
$E C V I=, 405$

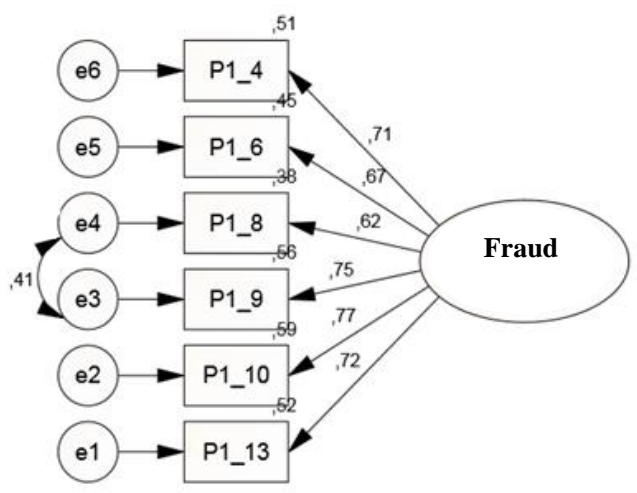

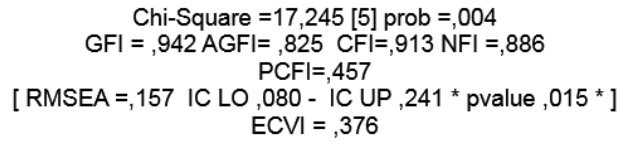

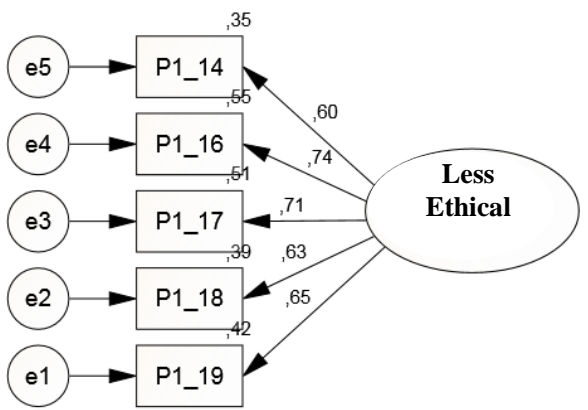

Figure 8: Confirmatory factor analysis of the dimensions Fraud Practices and More Creative and Less Ethical Practices

In Fraud Practices case, to maximize adjustment, it was necessary to include the reciprocal effect between P1_8 and P1_9. This makes sense from a Fraud Practice point of view as both deal with fraud in the recognition of revenue.

Table 8 presents the statistics of the Less Creative and Most Ethical dimension variables in relation to their internal consistency, ie Cronbach's Alpha if one item of the dimension variables is deleted. The results reveal an internal consistency index, Cronbach's Alpha of 0.72, whose value is of acceptable level.

Table 8: Cronbach's Alpha of the Less Creative and More Ethical Practices Dimension

\begin{tabular}{|crrr|r|r|}
\hline Less Creative and More Ethical Practices Dimesion & $\begin{array}{r}\text { Scale } \\
\text { Mean if } \\
\text { Item } \\
\text { Deleted }\end{array}$ & $\begin{array}{r}\text { Scale } \\
\text { Variance } \\
\text { if Item } \\
\text { Deleted }\end{array}$ & $\begin{array}{r}\text { Corrected } \\
\text { Item-Total } \\
\text { Correlation }\end{array}$ & $\begin{array}{r}\text { Cronbach's } \\
\text { Alpha if } \\
\text { Item } \\
\text { Deleted }\end{array}$ \\
\hline $\begin{array}{l}1.5 \quad \text { Recognition of actuarial gains / losses by opting } \\
\text { for the method to obtain the desired } \\
\text { benchmarks. }\end{array}$ & 9,90 & 9,000 & 0,484 & 0,683 \\
$1.7 \quad \begin{array}{l}\text { Sale of superfluous goods at the end of the year } \\
\text { for recognition of gains. }\end{array}$ & 8,93 & 8,773 & 0,311 & 0,795 \\
$\begin{array}{l}1.11 \text { Inventory measurement opting for the most } \\
\text { favorable costing formula. }\end{array}$ & 9,46 & 7,059 & 0,675 & 0,561 \\
$\begin{array}{c}1.12 \text { Asset valuation using discount rates in the } \\
\text { present value calculation, opting for the most } \\
\text { favorable technique. }\end{array}$ & 9,36 & 7,687 & 0,645 & 0,588 \\
\hline
\end{tabular}


In terms of corrected item - total correlation corrected values range between a minimum of 0.31 and a maximum of 0.67. In terms of eventual improvement of the Alpha index, if P1_7 was eliminated, it would eventually increase Alpha, to 0.79 , but as the value is adequate is to stay with the solution composed of 4 items. Figure 9 presents the confirmatory factor analysis of the Less Creative and Most Ethical Practices dimension. The GFI, NFI, CFI, AGFI adjustment values for the Less Creative and Most Ethical Practices dimension are within the expected values.

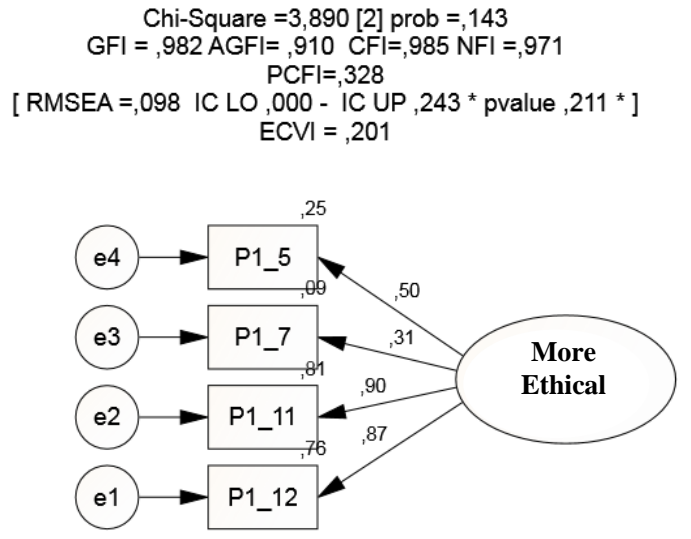

Figure 9: Confirmatory factor analysis of the Less Creative and More Ethical Practices Dimension

Table 9 presents the statistics of the variables of the dimension creatives practice in the result, as well as Cronbach's Alpha levels if one item of the dimension variables is deleted.

Table 9: Cronbach's Alpha of the Dimension Creatives Practices in Earnings

\begin{tabular}{|c|c|c|c|c|c|}
\hline & $\frac{\text { Earnings Creative Practices Dimesion }}{\text { - No. of items 3, Cronbach's Alpha 0,65 }}$ & $\begin{array}{r}\text { Scale } \\
\text { Mean if } \\
\text { Item } \\
\text { Deleted }\end{array}$ & $\begin{array}{r}\text { Scale } \\
\text { Variance if } \\
\text { Item } \\
\text { Deleted }\end{array}$ & $\begin{array}{r}\text { Corrected } \\
\text { Item-Total } \\
\text { Correlation }\end{array}$ & $\begin{array}{r}\text { Cronbach's } \\
\text { Alpha if } \\
\text { Item } \\
\text { Deleted }\end{array}$ \\
\hline 1.1 & $\begin{array}{l}\text { Postponement of equipment maintenance } \\
\text { from December to March to avoid damaging } \\
\text { the stock market price. }\end{array}$ & 5,48 & 4,293 & 0,358 & 0,686 \\
\hline 1.2 & $\begin{array}{l}\text { Recognition of expenditures in the current } \\
\text { year, which were only planned for next year, } \\
\text { because profit is above forecast. }\end{array}$ & 5,86 & 3,495 & 0,536 & 0,438 \\
\hline 1.3 & $\begin{array}{l}\text { Postponement of spending specialization from } \\
\text { March to April to achieve quarterly targets. }\end{array}$ & 5,60 & 4,101 & 0,495 & 0,508 \\
\hline
\end{tabular}

Regarding Earnings Creative Practices dimension, it can be observed that although the value is slightly below the expected $0.65<0.7$, the corrected item-total correlation values vary between a minimum of 0.36 and a maximum of 0.54 . In relation to a possible improvement the Alpha could be increased if it removed the P1_1 Postponement of equipment maintenance from December to March to avoid damaging the stock market price, to an even closer value than is considered standard. However, as this value is considered sufficient, it was decided to consider this dimension with the three-item composition. This model is in its confirmatory structure considered saturated, that is, with 0 degrees of freedom, this happens when it contains the same number of parameters as variance-covariance (Lei \& Wu, 2007) so it was not possible to 
calculate the measurements of $X^{2}$ based adjustment goodness of the model, choosing not to present its confirmatory structure.

Regarding the statistics of the variables of the Disclosure Practices dimension, it is not possible to calculate Cronbach's Alpha levels if one item of the dimension variables is eliminated because the dimension is composed of only two variables. Considering the literature review, and relating it with these results, it is possible to conclude that there is no exact definition of fraud in financial reporting widely accepted in all countries, nor consensus on the distinction between fraud and creative accounting. The theoretical framework and the position adopted in this investigation regarding the definitions of creative accounting, accounting fraud and accounting manipulation have support in these results. Thus, it is possible that creative accounting practices are not considered accounting frauds, as creative accounting is perceived by accountants differently than fraud.

It is concluded that both creative accounting practices and fraud practices are largely dependent on practices and decisions that address ethical issues, whereas fraud implies proving or evidencing that applicable standards, with which the financial statements must conform, have been adulterously misrepresented.

The results of this study match with previous authors, for example with Saludas (1999) definition of creative accounting has a kind of art where great accounting artists take advantage of the facilities offered by regulatory rigor to create a plot that allows them to mirror the desired corporate image and with Gadea and Callao (1999) in Saludas (1999) when they argue that creative accounting consists in taking advantage of the possibilities offered by accounting standards, such as opportunities for subjectivity, choice or legal voids, with a view to financially reporting a desired image of the company, not necessarily real.

Table 10 presents the average, standard deviation, minimum and maximum of the five dimensions of creative accounting.

Table 10: Creative Accounting Dimension Results

\begin{tabular}{|lccrr|}
\hline \multicolumn{1}{c}{ Dimensions } & Average & St.D. & Min. & Max. \\
\hline Fraud practices & 2,25 & 0,90 & 1 & 5 \\
More creative and less ethical practices & 2,37 & 0,76 & 1 & 5 \\
Less creative and more ethical practices & 3,14 & 0,91 & 1 & 5 \\
Disclosure creative practices & 3,37 & 1,23 & 1 & 5 \\
Earnings creative practices & 2,82 & 0,92 & 1 & 5 \\
\hline Manipulation practices & 2,79 & 0,64 & 1 & 5 \\
\hline
\end{tabular}

Fraud Practices have an average value of less than $\mathrm{Xm}=2.25$ indicating a higher degree of discomfort in ethical terms followed by the Most Creative and Less Ethical Practices which have a mean value of Xm = 2.37 .

Table 11 presents the mean, standard deviation, minimum and maximum of the creative accounting variables and the five dimensions. The average value, standard deviation, minimum, and maximum of the five dimensions of creative accounting were based on a new variable that was created and consists of the average of the cases (or units) that make up the dimension. For the purpose of descriptive statistics and interpretation of results, it was worked with the former that is, with the ones calculated, based on the arithmetic average of the items that compose it. However, for the subsequent follow-up of the analysis, were created and worked composite variables related to the dimensions of creative accounting that is, weighted on the total effects of the items that compose each of the dimensions, aiming to make them closer to the reality, because the items have distinct contributions to the formation of each of the generated dimensions. 
Table 11: Creative Accounting Dimension Results

\begin{tabular}{|c|c|c|c|c|c|c|}
\hline & $\begin{array}{l}\text { Creative Accounting Dimensions } \\
\text { (1- total discomfort to } 5 \text { - ethical and legitimate practice) }\end{array}$ & $\mathbf{N}$ & Average & St.D. & Min. & Max. \\
\hline 1. & Fraud Practices & & 2,25 & 0,90 & 1 & 5 \\
\hline 1.4 & $\begin{array}{l}\text { Recognition of expenses with training activities as intangible } \\
\text { assets. }\end{array}$ & 100 & 2,45 & 1,250 & 1 & 5 \\
\hline 1.6 & Recognition of expenses related with non-realized overtime work. & 100 & 1,73 & 1,081 & 1 & 5 \\
\hline 1.8 & $\begin{array}{l}\text { Recognition of revenue from services billed and charged but not } \\
\text { yet provided. }\end{array}$ & 100 & 2,18 & 1,158 & 1 & 5 \\
\hline 1.9 & $\begin{array}{l}\text { Recognition of year-end sales associated with a repurchase } \\
\text { agreement. }\end{array}$ & 100 & 2,51 & 1,202 & 1 & 5 \\
\hline 1.10 & $\begin{array}{l}\text { Recognition of investment grant fully as income in the moment of } \\
\text { award. }\end{array}$ & 100 & 2,43 & 1,217 & 1 & 5 \\
\hline 1.13 & $\begin{array}{l}\text { Reclassification of tangible fixed assets related to the production } \\
\text { process to current assets held for sale to avoid depreciation. }\end{array}$ & 100 & 2,20 & 1,035 & 1 & 5 \\
\hline 2. & More Creative and Less Ethical Practices & & 2,37 & $\mathbf{0 , 7 6}$ & 1 & 5 \\
\hline 1.14 & $\begin{array}{l}\text { Asset depreciation ignoring the separation of parts whose cost is } \\
\text { significant in relation to the total cost of the item. }\end{array}$ & 100 & 2,48 & 1,000 & 1 & 5 \\
\hline 1.16 & $\begin{array}{l}\text { Classification of current liabilities as non-current liabilities in } \\
\text { order to favor the entity's ratios. }\end{array}$ & 100 & 2,35 & 0,999 & 1 & 5 \\
\hline 1.17 & Change guarantee rates to recognize lower amounts of provisions. & 100 & 2,21 & 0,913 & 1 & 5 \\
\hline 1.18 & $\begin{array}{l}\text { Non-recognition, at the end of the year, of the obligation (liability) } \\
\text { regarding the distribution, previously announced, of part of the } \\
\text { profits to employees. }\end{array}$ & 100 & 1,94 & 0,983 & 1 & 5 \\
\hline 1.19 & $\begin{array}{l}\text { Not disclosing a liability for asset decommissioning because it is } \\
\text { not possible to establish a reasonable and reliable estimate. }\end{array}$ & 100 & 2,88 & 1,183 & 1 & 5 \\
\hline & Less Creative and More Ethical Practices & & 3,14 & 0,91 & 1 & 5 \\
\hline & $\begin{array}{l}\text { Recognition of actuarial gains / losses by opting for the method to } \\
\text { obtain the desired benchmarks. }\end{array}$ & 100 & 2,65 & 1,067 & 1 & 5 \\
\hline & $\begin{array}{l}\text { Sale of superfluous goods at the end of the year for recognition of } \\
\text { gains. }\end{array}$ & 100 & 3,62 & 1,384 & 1 & 5 \\
\hline 1.11 & $\begin{array}{l}\text { Inventory measurement opting for the most favorable costing } \\
\text { formula. }\end{array}$ & 100 & 3,09 & 1,272 & 1 & 5 \\
\hline 1.12 & $\begin{array}{l}\text { Asset valuation using discount rates in the present value } \\
\text { calculation, opting for the most favorable technique. }\end{array}$ & 100 & 3,19 & 1,169 & 1 & 5 \\
\hline 4. & Disclosure Creative Practices & & 3,37 & 1,23 & 1 & 5 \\
\hline 1.20 & $\begin{array}{l}\text { Non-disclosure of an unrecognized contingent loss whose } \\
\text { probability of occurrence is more than remote. }\end{array}$ & 100 & 3,26 & 1,292 & 1 & 5 \\
\hline 1.21 & $\begin{array}{l}\text { Disclosure of voluntary information to increase company market } \\
\text { value. }\end{array}$ & 100 & 3,47 & 1,446 & 1 & 5 \\
\hline 5. & Earnings Creative Practices & & 2,82 & 0,92 & 1 & 5 \\
\hline 1.1 & $\begin{array}{l}\text { Postponement of equipment maintenance from December to March } \\
\text { to avoid damaging the stock market price. }\end{array}$ & 100 & 2,99 & 1,219 & 1 & 5 \\
\hline 1.2 & $\begin{array}{l}\text { Recognition of expenditures in the current year, which were only } \\
\text { planned for next year, because profit is above forecast. }\end{array}$ & 100 & 2,61 & 1,254 & 1 & 5 \\
\hline 1.3 & $\begin{array}{l}\text { Postponement of spending specialization from March to April to } \\
\text { achieve quarterly targets. }\end{array}$ & 100 & 2,87 & 1,116 & 1 & 5 \\
\hline \multicolumn{3}{|c|}{ Average } & 2,79 & 0,64 & 1 & 5 \\
\hline
\end{tabular}

- The following are the maximum average values:

$\circ$ The sale of superfluous goods at the end of the year for recognition of gains $(\mathrm{Xm}=3.62$ and $\mathrm{s}=$ 1.384); 
○ Disclosure of voluntary information to increase company market value (Xm $=3.47$ and $\mathrm{s}=1.446)$;

- Non-disclosure of an unrecognized contingent loss whose probability of occurrence is more than remote $(\mathrm{Xm}=3.26$ and $\mathrm{s}=1.292)$.

- The following are the minimum average values:

O Recognition of expenses related with non-realized overtime work $(\mathrm{Xm}=1.73$ and $\mathrm{s}=1.081)$;

- Non-recognition, at the end of the year, of the obligation (liability) regarding the distribution, previously announced, of part of the profits to employees $(\mathrm{Xm}=1.94$ and $\mathrm{s}=0.993)$;

○ Recognition of investment grant fully as income in the moment of award ( $\mathrm{Xm}=2.43$ and $\mathrm{s}=1.217)$.

Figure 10 shows the average of creative accounting main dimensions, where values around 1 mean total discomfort and values around 5 mean an ethical and legitimate practice. The main conclusion to be drawn about accounting manipulation practices is that accountants are more ethically uncomfortable with creative accounting practices that are closer to the limits of fraud and show less ethical discomfort with creative accounting practices that are more distant from fraud.

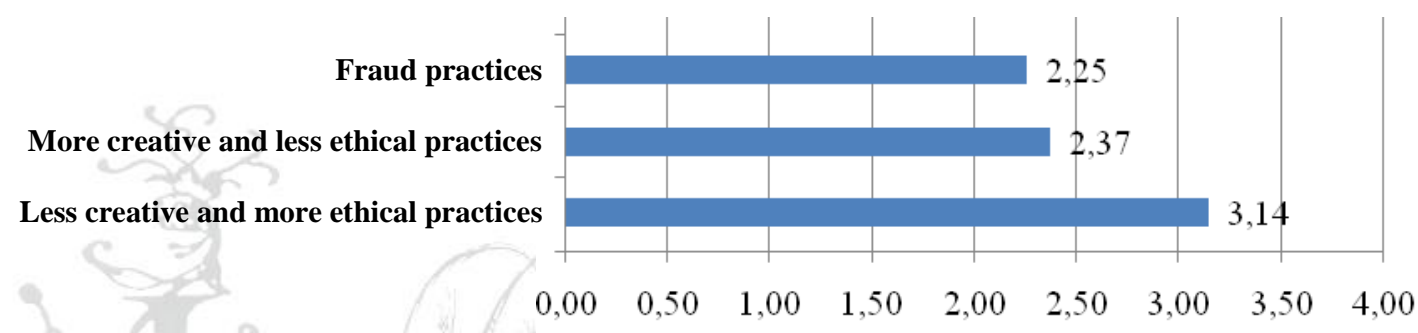

Figure 10: Average of the level of ethical comfort in creative accounting main dimensions

In a more detailed analysis of each of the main dimensions of creative accounting, the Fraud Practices dimension is characterized by fraudulent accounting manipulation practices. This dimension has the average value $\mathrm{Xm}=2.25$ and the standard deviation $\mathrm{s}=0.90$. In this five-variable dimension, the one with the highest average value is 1.9 Recognition of year-end sales associated with a repurchase agreement (Xm $=2.51 \mathrm{~s}=1.202$ ), indicating a reasonable to large degree of ethical discomfort in its recognition. The variable with the lowest average score is 1.6 Recognition of expenses related with non-realized overtime work. $(\mathrm{Xm}=1.73$ and $\mathrm{s}=1.081)$, indicating the highest degree of discomfort in ethical terms regarding its recognition.

The Most Creative and Unethical Practices dimension is characterized by creative accounting practices that are closer to the limits of fraud. This dimension has the average value $\mathrm{Xm}=2.37$ and the standard deviation $\mathrm{s}=0.76$. In this dimension, with six variables, the one with the highest average value is 1.19 Not disclosing a liability for asset decommissioning because it is not possible to establish a reasonable and reliable estimate. $(\mathrm{Xm}=2.88$ and $\mathrm{s}=1.183)$, indicating a discomfort in reasonable to great ethical terms in view of its realization. The variable with the lowest average score is 1.18 Non-recognition, at the end of the year, of the obligation (liability) regarding the distribution, previously announced, of part of the profits to employees. $(\mathrm{Xm}=1.73$ and $\mathrm{s}=1.081)$, indicating a degree of major discomfort in ethical terms, in view of its realization.

The Less Creative and More Ethical Practices dimension is characterized by creative accounting practices that are further from the limits of fraud. This dimension has the average value $\mathrm{Xm}=3.14$ and the standard deviation $s=0.91$. In this dimension, with four variables, the one with the highest average value is 1.7 . Sale of superfluous goods at the end of the year for recognition of gains $(\mathrm{Xm}=3.62$ and $\mathrm{s}=1.384)$, indicating some reasonable discomfort in ethical terms with their realization. The variable with the lowest average 
score is the 1.5 Recognition of actuarial gains / losses by opting for the method to obtain the desired benchmarks $(\mathrm{Xm}=2.65$ and $\mathrm{s}=1.067)$, indicating a reasonable to large degree of ethical discomfort in the realization of its recognition.

These results are in accordance with the more narrower definition of creative accounting according to the Chartered Institute of Management Accounting (2000) showing that while complying with all regulations it is possible to give a biased impression (generally favorable) of the company's performance.

\section{Conclusion}

This research exposes and analyses the association between creative accounting and decisions that address ethical accounting issues. Considering the literature review it is possible to conclude that there is no exact definition of fraud in financial reporting widely accepted in all countries, nor consensus on the distinction between fraud and creative accounting. From the investigated association between creative accounting and ethics, it is concluded that both creative accounting practices and fraud practices are largely dependent on practices and decisions that address ethical issues, whereas fraud implies proving or evidencing that applicable standards, with which the financial statements must conform, have been adulterously misrepresented. Therefore, with the results of this study, the theoretical framework and the position adopted in this investigation regarding the definitions of creative accounting, accounting fraud and accounting manipulation have support in these results. Thus, it is possible that creative accounting practices are not considered accounting frauds, as creative accounting is perceived by accountants differently than fraud.

The main conclusion to be drawn about accounting manipulation practices is that accountants are more ethically uncomfortable with creative accounting practices that are closer to the limits of fraud and show less ethical discomfort with creative accounting practices that are more distant from fraud.

\section{References}

Barnea, A., Ronen, J., \& Sadan, S. (1975, January). The implementation of accounting objectives: An application to extraordinary items. The Accounting Review, 58-68.

Barnea, A., Ronen, J., \& Sadan, S. (1976, January). Classificatory smoothing of income with extraordinary items. The Accounting Review, 110-22.

Belkaoui, A. R. (1997), "Accounting theory", the dryden press. ( $3^{\mathrm{a}}$ ed). Harcourt Brace \& Company.

Black, E. L., Sellers, K. F., \& Manly, T. S. (1998, Nov/Dec). Earnings management using asset sales: an international study of countries allowing noncurrent asset revaluation. Journal of Business Finance \& Accounting, 25(9), 1287-1317.

Breton, G., \& Taffler, R. J. (2001). Accounting information and analyst stock recommendations: A content analysis approach. Accounting and business research, 32(2), 92-101.

Copeland, R. M. (1968). Income smoothing. Journal of Accounting Research, Empirical Research in Accounting, Selected Studies 6 (Supplement), 101-116.

Gowthorpe, C., \& Amat, O. (2005). Creative accounting: Some ethical issues of macro- andmicromanipulation. Journal of Business Ethics, 57, 55-64.

Griffiths, I. (1986). Creative accounting: how to make your profits what you want them to be. Universidade de Michigan: Unwin Paperbacks.

Griffiths, I. (1988), Contabilidad creativa: como hacer que los beneficios aparezcan de modo más favorable. Bilbao: Duesto.

Hair, J. F. Jr., Anderson, R. E., Tatham, R. L., \& Black, W. C., (1998). Multivariate data analysis. (5th ed). Upper Saddle River, NJ: Prentice-Hall, Inc.

Hair, J. F. Jr., Black, W. C. Babin, B. J., Anderson, R. E., (2010). Multivariate data analysis. (7th ed). New Jersey: Prentice Hall.

Hendriksen, E. S., \& Breda, M. V. (1992). Accounting Theory. 
Jameson, M. (1988). A practical guide to creative accounting. London.

Johnson, L. T., Reither, C., \& Swieringa, J. (1995, Dec). Toward reporting comprehensive income. Accounting Horizons, 138-147.

Jones, J. (1991). Earnings management during import relief investigations. Journal of Accounting Research 29(2), 193-228.

Jones, M. (2011). Creative accounting, fraud and international scandals. England, John Wiley Sons Ltd.

Kaplan. (2010). Professional ethics in accounting and finance, combined text and workbook - 2010-11.

Moore, M. L. (1973, Spring). Management changes and discretionary accounting decisions. Journal of Accounting Research, 100-107.

Mulford, C. W. \& Comiskey, E. E. (2002). Financial numbers game: Detecting Creative Accounting Practices. Wiley.

Naser, K. H. M. (1993). Creative Financial Accounting, it's nature and use. Prentice Hall, Londres.

Nogueira, J. (2012). O justo valor e a ética na contabilidade e nos negócios. Revista de contabilidade e finanças, 110, 4-15.

Reis, Elizabeth (2011), Estatística Multivariada Aplicada (2ª ed.). Lisboa: Edições Sílabo.

Revsine, L. D., Collins, \& Johson, W. (1999). Financial reporting and analysis upper.

Ronen, J., \& Sadan, S. (1975, Spring). Classificatory smoothing: alternative income models. Journal of Accounting Research, 133-149.

Sá, A. L. d. (2010). Alisamento de resultados e Normas Internacionais de Contabilidade. Contabilidade \& Empresas, 12.

Smith, T. (1992). Accounting for growth: stripping the camouflage from company accounts.

Stiglitz, J. E. (2003). The roaring nineties: a new history of the world's most prosperous decade.

Stolowy, H., \& Breton, G. (2004). Accounts manipulation: a literature review and proposed conceptual framework. Review of Accounting and Finance, 3(1), 5 - 92. doi: 10.1108/eb043395

Thompson, B. (2000). Ten commandments of structural equation modeling. In L.G. Grimm \& P.R. Yarnold (Eds.), reading and understanding more multivariate statistics 261-283. Washington, DC: American Psychological Association. 